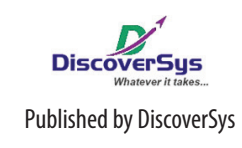

\section{Masalah Demam Berdarah Dengue (DBD) dan Ketersediaan Vaksin}

Dewa Nyoman Wirawan*

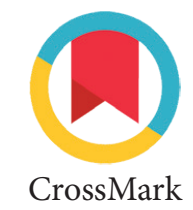

${ }^{1}$ Program Studi Magister IImu Kesehatan Masyarakat Universitas Udayana,

${ }^{2}$ Bagian IImu Kedokteran Komunitas dan IImu Kedokteran Pencegahan Fakultas Kedokteran Universitas Udayana

*Korespondensi penulis: Dewa Nyoman Wirawan, Program Studi Magister IImu Kesehatan Masyarakat Universitas Udayana, Bagian IImu Kedokteran Komunitas dan IImu Kedokteran Pencegahan Fakultas Kedokteran Universitas Udayana

wirawandewa48@gmail.com
Secara global, jumlah kasus demam dengue terus meningkat dengan sangat cepat. Jumlah kasus yang dilaporkan ke Badan Kesehatan Dunia atau World Health Organization (WHO) pada tahun 1996-2005 hanya sekitar 0,4 juta sampai 1,3 juta dalam satu tahun. Pada tahun 2010 telah mencapai 2,2 juta dan 2015 menjadi 3,2 juta. ${ }^{1}$ Lima negara yang melaporkan rata-rata jumlah kasus DBD paling banyak ke WHO dalam satu tahun pada kurun waktu 20042010 yaitu tertinggi dari Brazil (447.446 kasus), Indonesia (129.435 kasus), kemudian disusul oleh Vietnam (91.321 kasus), Mexico (75.353 kasus) dan Venezuela (61.612 kasus). ${ }^{1}$

Secara global, WHO mencanangkan bahwa pada tahun 2020 morbiditas DBD harus diturunkan sebanyak 25\% dan tingkat kematian harus diturunkan sebanyak 50\%. ${ }^{1}$ Untuk mencapai target tersebut diperlukan berbagai strategi, baik penanggulangan vektor maupun dengan upaya lainnya termasuk program vaksinasi.

Pengembangan vaksin dengue telah dilakukan sejak 20 tahun yang lalu mulai dari penelitian Fase I, II, dan III. Sanofi Pasteur melaksanakan uji klinis (clinical trial) Fase III vaksin dengue sejak tahun 2011 di 10 negara yang mempunyai kasus dengue cukup tinggi, yaitu lima negara di Amerika Latin dan lima negara di Asia., ${ }^{2,3}$ Sepuluh negara tersebut adalah: Indonesia, Malaysia, Philippines, Thailand, Vietnam, Brazil, Columbia, Honduras, Mexico, dan Puerto Rico. Jumlah subjek dalam penelitian ini lebih dari 30.000 anak, yaitu 10.275 anak umur 2-14 tahun di lima negara di Asia dan 20.869 anak umur 9-16 tahun di lima negara Amerika Latin.,3 Hasil penelitian telah dipublikasikan di Jurnal Lancet terbitan 11 Juli $2014^{4}$ dan di Jurnal New England of Medicine terbitan 28 Juli 2015. ${ }^{2}$ Untuk mengetahui efikasi dan keamanan vaksin dalam waktu yang lebih panjang, penelitian di 10 negara di atas masih dilanjutkan sampai dengan akhir tahun 2017.,3,4 Hasil penelitian menunjukkan bahwa efikasi vaksin untuk mencegah demam dengue (infeksi dengue yang simtomatis) adalah 65,6\%, mencegah kejadian demam dengue untuk dirawat di rumah sakit sebesar 80,8\% dan mencegah DBD berat sebesar 92,9\%. ${ }^{2,3}$

Vaksin tersebut telah didaftarkan di 12 negara termasuk Indonesia. ${ }^{2}$ Surat ijin edar vaksin ini telah diterbitkan oleh Badan Pengawasan Obat dan Makanan (BPOM) Indonesia pada bulan September 2016 dan saat ini vaksin telah tersedia di pasaran di Indonesia. BPOM memberikan ijin edar hanya untuk anak umur 9-16 tahun karena efikasi vaksin yang paling tinggi adalah pada kelompok umur tersebut sedangkan pada anak umur dibawah 9 tahun terutama pada anak umur 2-5 tahun, efikasi vaksin dijumpai kurang begitu baik. ${ }^{2,3,4}$ Di beberapa negara selain Indonesia, ijin edar vaksin diterbitkan untuk penduduk umur 9 tahun ke atas walaupun populasi penelitian hanya pada anak umur sampai 16 tahun. ${ }^{2}$ Vaksin harus diberikan secara suntikan di kulit atau intrakutan sebanyak 3 kali dengan jarak waktu 6 bulan. $^{2}$ Harga vaksin di pasaran komersial di Indonesia masih cukup mahal yaitu sekitar 1 juta per satu kali suntik atau 3 juta untuk 3 kali suntik. Sebagaimana lazimnya, harga akan bisa lebih rendah bila dibeli dalam jumlah yang cukup banyak dan dipergunakan secara masal.

Untuk menurunkan morbiditas DBD sebanyak $25 \%$ dan mortalitas sebanyak $50 \%$, WHO merekomendasikan perlunya kombinasi berbagai upaya terutama penanggulangan vektor dan program vaksinasi. ${ }^{1,2}$ Program vaksinasi direkomendasikan pada daerah-daerah endemis terutama daerah dengan persentase penduduk yang sero-positif dengue di atas 50\%. ${ }^{2}$ Mengingat tingginya kasus DBD di Indonesia, untuk mengetahui efektivitas vaksin di masyarakat diperlukan uji coba pada daerah-daerah dengan tingkat endemisitas yang tinggi dan sekalian untuk mengetahui besaran biaya yang diperlukan untuk mencegah kasus DBD dalam kawasan yang lebih luas atau secara nasional.

\section{DAFTAR PUSTAKA}

1. World Health Organization. Global Strategy for Dengue Prevention and Control 2012-2020. 2012. Available at http://reliefweb.int/sites/reliefweb.int/files/ resources/9789241504034_eng.pdf.

2. World Health Organization. Weekly Epidemilogical Record ; 2016; 91(30): 349-364.

3. Hadinegoro SR, et al. Efficacy and Long-Term Safety of Dengue Vaccine in Regions of Endemic Disease. New England Journal of Medicine; 2015; 373(13):1195-1206.

4. Capeding MR, Tran NH, Hadinegoro SR, et al. Clinical efficacy and safety of a novel tetravalent dengue vaccine in healthy children in Asia: a phase 3, randomised, observer-masked, placebo-controlled trial. Lancet 2014;384:1358-65. 2. Villar L, Dayan GH, Arredondo-Garcí.

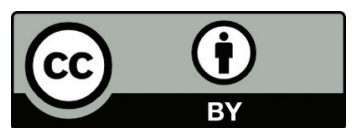

This work is licensed under a Creative Commons Attribution 